\title{
FAKTOR FAKTOR YANG MEMENGARUHI KINERJA AUDITOR SERTA DAMPAKNYA TERHADAP PROFESIONALISME
}

\author{
R. Muchamad Noch \\ m_noch@yahoo.co.id \\ Sri Indri Winata \\ Universitas Pasundan
}

diterima: 2/10/2019; direvisi: 10/10/2019; diterbitkan: 30/10/2019

\begin{abstract}
This study aims to examine factors that affect to Auditor Performance and its impact on Auditor Professionalism. The sample of this research is Auditor at Public Accountant Office in working area of Bandung city. The result of research that has been done on the second sub-structure model shows the influence of auditor performance to auditor professionalism of $61,1 \%$, then the effect of organizational commmitment on auditor professionalism through auditor performance as intervening variable that is equal to $32,7 \%$, and the effect of implementation leadership style on auditor professionalism through auditor performance as intervening variable that is equal to $23,8 \%$, and the effect of implementation understanding of good governance on auditor professionalism through auditor performance as intervening variable that is equal to $31,7 \%$.
\end{abstract}

Keywords: organizational commmitment; leadership style; understanding of good governance; auditor performance; auditor professionalism

\begin{abstract}
Penelitian ini bertujuan untuk menguji Faktor-Faktor yang memengaruhi Kinerja Auditor Serta Dampaknya Terhadap Profesionalisme Auditor. Sampel pada penelitian ini adalah Auditor pada Kantor Akuntan Publik di Wilayah Bandung. Metode yang digunakan dalam penelitian ini adalah metode deskriptif dan verifikatif. Hasil penelitian yang telah dilakukan pada model sub-struktur kedua menunjukan kinerja auditor terhadap profesionalisme auditor sebesar $61,1 \%$, kemudian besarnya pengaruh komitmen organisasi terhadap profesionalisme auditor melalui kinerja auditor sebagai variabel intervening yaitu sebesar $32,7 \%$, pengaruh gaya kepemimpinan terhadap profesionalisme auditor melalui kinerja auditor sebagai variabel intervening yaitu sebesar $23,8 \%$, dan pengaruh pemahaman good governance terhadap profesionalisme auditor melalui kinerja auditor sebagai variabel intervening yaitu sebesar 31,7 .
\end{abstract}

Kata Kunci: komitmen organisasi; gaya kepemimpinan; pemahaman good governance; kinerja auditor; profesionalisme auditor 


\section{PENDAHULUAN}

Berkembangnya perusahaan pada saat ini mempengaruhi profesi akuntan publik. Semakin berkembangnya perusahan pada umumnya, maka semakin berkembang pula profesi akuntan publik. Di negara yang mayoritas perusahaan berbentuk perusahaan perseorangan, profesi akuntan publik kurang berkembang. Namun, di negara yang terdapat banyak perusahaan seperti di Indonesia yang terdapat banyak perusahaan berbentuk perseroan terbatas yang bersifat terbuka, profesi akuntan publik semakin dibutuhkan karena sangat besar kemungkinan manajamen perusahaan terpisah dengan pemilik perusahaan. Karena pemilik perusahaan hanya sebagai penanam modal. Oleh karena itu, mereka sangat membutuhkan informasi keuangan yang dapat dipercaya yang dihasilkan manajamen.

Laporan keuangan yang disajikan merupakan bentuk pertanggung-jawaban manajemen yang dapat memberikan informasi laporan keuangan yang dapat dipercaya kepada pihak luar seperti kreditur, pemerintah, investor pasar modal, dan lainnya. Laporan keuangan ini digunakan sebagai informasi untuk membantu para pengguna dan para pengambil keputusan (Boynton et. al, 2008:53). Maka dari itu laporan keuangan harus teruji dalam kebenarannya. Oleh sebab itu perlu diadakannya kegiatan pemeriksaan dari pihak yang independen yaitu oleh akuntan publik untuk menilai dapat atau tidak dapat dipercayainya suatu laporan keuangan yang diberikan manajamen. Laporan keuangan yang telah di audit oleh akuntan publik memiliki kewajaran yang dapat lebih dipercaya dibandingkan dengan laporan keuangan yang tidak atau belum diaudit. Selain itu, masyarakat menilai bahwa profesi auditor diharapkan dapat melakukan penilaian yang bebas, dapat dipercaya, serta tidak memihak terhadap siapapun.

Auditor dalam melakukan tugas pemeriksaan juga harus profesional. Karena sikap profesionalisme yang dimiliki auditor menandakan bahwa auditor tersebut dapat menghasilkan kinerja auditor yang memuaskan dan baik. Dengan begitu kepercayaan dari masyarakat pun akan tetap melekat. Jadi sangatlah diperlukan sikap profesionalisme tersebut dalam menyelesaikan tugastugas dengan tepat waktu, namun auditor sebagai profesi kepercayaan masyarakat mulai banyak dipertanyakan kinerjanya dalam hal memeriksa dan menilai laporan suatu perusahaan.. Hal ini didukung oleh bukti yang semakin banyaknya fenomena kinerja auditor yang menurun dalam hal pemeriksaan ataupun penilaian kepada perusahaan sebagai auditee.

Untuk memperbaiki kinerja itu ada beberapa faktor yang mempengaruhinya, dimulai dengan membangun komitmen organisasi yang baik. Luthans (2017:249) menyatakan bahwa komitmen organisasional adalah sikap yang merefleksikan loyalitas karyawan pada organisasi dan proses berkelanjutan dimana anggota organisasi mengekpresikan perhatiannya terhadap organisasi dan keberhasilan serta kemajuan yang berkelanjutan. Dapat dibilang komitmen organisasi erat dengan aspek psikologi karena dalam penerimaan dan kepercayaan terhadap nilai-nilai tujuan organisasi muncul sehingga menanamkan sikap loyalitas pada pegawai. Komitmen organisasi juga merupakan nilai personal, yang terkadang mengacu pada sikap loyal pada perusahaan atau komitmen pada perusahaan

Selain komitmen organisasi, yang dapat mempengaruhi kinerja auditor adalah gaya kepemimpinan. Hal ini di dukung oleh teori menurut Kariyanti (2017:34) menyatakan Gaya kepemimpinan adalah sifat, kebiasaan, tempramen, watak dan kepribadian dengan orang lain yang digunakan oleh seseorang pada saat orang tersebut mencoba mempengaruhi prilaku orang lain atau bawahan.

Adapun, faktor lain yang dapat mempengaruhi kinerja auditor yaitu pemahaman good governance. Menurut Suwanto (2015: 82) Pemahaman good governance merupakan wujud penerimaan akan pentingnya suatu perangkat peraturan atau tata kelola yang baik untuk mengatur hubungan, fungsi dan kepentingan berbagai pihak dalam urusan bisnis maupun pelayanan publik.

Pemahaman atas good governance adalah untuk menciptakan keunggulan manajemen kinerja baik pada perusahaan bisnis ataupun perusahaan jasa, serta lembaga pelayanan publik/pemerintahan. Jadi dapat disimpulakn apabila seorang auditor paham mengenai good governance, itu dapat mempengaruhi kinerja auditornya. Terutama dalam pengambilan keputusan saat pemberian opini.

Penelitian ini merupakan pengembangan dari penelitian yang telah dilakukan sebelumnya oleh Akriyanto (2012). Pengaruh Independensi, Gaya Kepemimpinan, Komitmen Organisasi dan Pemahaman Good Governance Terhadap Kinerja Auditor. Hasil dari penelitian tersebut bahwa independensi, komitmen organisasi, gaya kepemimpinan dan pemahaman good governance berpengaruh positif terhadap kinerja auditor. Perbedaan penelitian ini dengan penelitian sebelumnya yaitu penulis menghilangkan variabel independensi dan menambahkan variabel profesionalisme auditor dengan metode analisis jalur. Tempat penelitian sebelumnya yaitu di Kantor Akuntan Publik di Surakarta dan Yogyakarta. Sedangkan penulis melakukan penelitian di Kantor Akuntan Publik yang berada di Kota Bandung.

Penelitian sebelumnya yang dilakukan oleh Putri dan Suraida (2014) yang berjudul Pengaruh Profesionalisme dan Komitmen Organisasi Terhadap Kinerja Internal Auditor. Yang membedakan penulis dengan peneliti sebelumnya yaitu menambahkan variabel Gaya Kepemimpinan dan Pemahaman Good Governance. Penelitian sebelumnya mengambil sampel 51 responden dari BUMN Sektor Industri Pengelolaan di Kota Bandung. Berdasarkan hasil penelitian sebelumnya, pengaruh komitmen organisasi berpengaruh positif terhadap kinerja internal auditor. 


\section{METODE}

Jenis penelitian ini menggunakan metode kuantitatif dengan penelitian primer/survey. Dalam penelitian ini pendekatan yang digunakan adalah deskriptif dan verifikatif. Tujuan dari penelitian ini adalah untuk membuat deskripsi atau gambaran secara sistematis, faktual dan akurat mengenai fakta, sifat, serta hubungan antara fenomena yang diselidiki. Ada dua instrument yang digunakan dalam penelitian ini yaitu menggunakan wawancara, dan angket metode tertutup. Indikatorindikator untuk kedua variabel tersebut kemudian dijabarkan oleh penulis menjadi sejumlah pertanyanpertanyaan sehingga diperoleh data primer. Data ini akan dianalisis dengan menggunakan uji statistika yang relevan untuk menguji hipotesis. Sedangkan teknik ukuran yang digunakan yaitu teknik Skala Likert.

Objek penelitian dalam penelitian ini mengenai pengaruh Komitmen Organisasi, Gaya Kepemimpinan dan Pemahaman Good Governance terhadap Kinerja Auditor serta Dampaknya Terhadap Profesionalisme Auditor yang pada 10 Kantor Akuntan Publik (KAP) di Kota Bandung yang terdaftar di Institut Akuntan Publik Indonesia (IAPI). Penelitian ini bertujuan untuk mengukur sejauh mana pengaruh Komitmen Organisasi, Gaya Kepemimpinan dan Pemahaman Good Governance terhadap Kinerja Auditor serta Dampaknya Terhadap Profesionalisme Auditor.

Analisis yang digunakan yakni analisis jalur (path analysis), Path Analysis digunakan untuk mengetahui hubungan ketergantungan langsung diantara satu set variabel. Adapun operasionalisasi akan disajikan pada Tabel 1. Agar dapat menggambarkan indikator-indikator yang digunakan dalam penelitian.

\section{HASIL}

Berdasarkan hasil perhitungan nilai rata-rata total skor jawaban dari 65 responden, komitmen auditor pada Kantor Akuntan Publik di Kota Bandung terhadap organisasi termasuk dalam kriteria "Sangat Tinggi". Artinya sebagian besar auditor pada Kantor Akuntan Publik di Kota Bandung sudah sangat berkomitmen dalam melaksanakan tugas audit.

Sementara itu gaya kepemimpinan pada Kantor Akuntan Publik di Kota Bandung termasuk dalam kriteria "Sangat Baik". Artinya sebagian besar auditor pada Kantor Akuntan Publik di Kota Bandung sudah memiliki gaya kepemimpinan yang sangat baik.

Adapun pemahaman auditor pada Kantor Akuntan Publik di Kota Bandung tentang good governance termasuk dalam kriteria "Sangat Paham". Artinya sebagian besar auditor pada Kantor Akuntan Publik di Kota Bandung sudah sangat memahami good governance.

Kinerja auditor pada Kantor Akuntan Publik di Kota Bandung termasuk dalam kriteria "Baik". Artinya sebagian besar auditor pada Kantor Akuntan Publik di Kota Bandung sudah menunjukkan kinerja yang baik. kemudian sebagian besar auditor pada Kantor Akuntan Publik di Kota Bandung sudah sangat profesional dalam melaksanakan tugasnya.

Adapun analisis verifikatif akan terlihat pada Gambar 1. diagram jalur pada pengujian struktur pertama, hasil pengujian hipotesis menunjukkan bahwa komitmen organisasi, gaya kepemimpinan dan pemahaman good governance secara simultan berpengaruh terhadap kinerja auditor pada Kantor Akuntan Publik di Kota Bandung, hasil uji F menunjukkan bahwa Fhitung $(29,794)$ lebih besar dibanding Ftabel $(2,755)$ dapat dilihat di Tabel 2. Besarnya kontribusi atau pengaruh dari komitmen organisasi, gaya kepemimpinan dan pemahaman good governance secara simultan terhadap kinerja auditor pada Kantor Akuntan Publik di Kota Bandung sebesar 59,4\%.

Berdasarkan hasil pengujian hipotesis parsial dapat disimpulkan bahwa komitmen organisasi berpengaruh terhadap kinerja auditor pada Kantor Akuntan Publik di Kota Bandung, terlihat dari hasil bahwa nilai thitung variabel komitmen organisasi $(4,954)$ lebih besar dari $t$ tabel $(2,000)$. Diikuti juga oleh pengujian hipotesis parsial untuk variabel gaya kepemimpinan terhadap kinerja auditor yang menunjukkan hasil nilai t hitung $(3,604)$ lebih besar dari ttabel $(2,000)$. Sementara variabel indepeden terakhir yakni pemahaman good governance juga berpengaruh positif signikan terhadap kinerja auditor dengan nilai thitung $(4,832)$ lebih besar dari ttabel $(2,000)$. Masing-masing pengaruh langsung dan tidak langsung yang diberikan oleh variabel independen terhadap kinerja auditor berturut-turut adalah 23,2\% (komitemen organisasi), 14,1\% (gaya kepemimpinan) dan 22,6\% (pemahaman good governance).

Pengujian sub struktur kedua pada Gambar 2. adalah pengaruh kinerja auditor terhadap profesionalisme auditor pada Kantor Akuntan Publik di Kota Bandung menghasilkan thitung variabel kinerja auditor $(9,943)$ lebih besar dari $t$ tabel $(1,998)$ dapat dilihat di Tabel 3. dan dinyatakan berpengaruh dengan kontribusi sebesar $61,1 \%$ sesuai pada Tabel 4 , artinya semakin baik kinerja akan membuat profesionalisme auditor pada Kantor Akuntan Publik di Kota Bandung semakin tinggi.

Hasil berikutnya adalah pengujian tidak langsung antar variabel. Berdasarkan hasil pengujian ditemukan bahwa terdapat pengaruh tidak langsung komitmen organisasi terhadap profesionalisme auditor melalui kinerja auditor sebesar 32,7\%. Hasil berikutnya juga memberikan bukti bahwa penerapan gaya kepemimpinan yang tepat akan membuat kinerja auditor makin baik sehingga berdampak pada meningkatnya profesionalisme auditor, dengan kontribusi sebesar $23,8 \%$. Terakhir yaitu secara tidak langsung terdapat pengaruh good governance terhadap profesionalisme auditor melalui kinerja auditor sebesar dengan pengaruh sebesar $31,7 \%$. 


\section{PEMBAHASAN}

Pembahasan pertama yakni pengaruh dari komiten organisasi terhadap kinerja auditor, adanya pengaruh menunjukkan komitmen organisasional dibangun atas dasar kepercayaan pekerja atas nilai-nilai organisasi, kerelaan pekerja membantu mewujudkan tujuan organisasi dan loyalitas untuk tetap menjadi anggota organisasi. Oleh karena itu, komitmen organisasi akan menimbulkan rasa ikut memiliki (sense of belonging) bagi pekerja terhadap organisasi. Jika pekerja merasa jiwanya terikat dengan nilai-nilai organisasional yang ada maka dia akan merasa senang dalam bekerja, sehingga kinerjanya dapat meningkat (Robbins dan Judge, 2016:267).

Dari segi kepemimpinan pimpinan di KAP menurut Wirjana dan Supardo (2005:223), gaya kepemimpinan merupakan norma perilaku yang digunakan seorang manajer pada saat ia mempengaruhi perilaku bawahannya. Seseorang yang menjalankan fungsi manajemen berkewajiban mempengaruhi karyawan yang dibawahinya agar mereka tetap melaksanakan tugas dengan baik, menghasilkan kinerja yang berkualitas, memiliki dedikasi terhadap organisasi dan tetap merasa berkewajiban untuk mencapai tujuan organisasi.

Didukung dari segi pemahaman good governance yang dimana Seorang auditor yang memahami good governance secara benar juga akan mempengaruhi perilaku profesional akuntan dalam berkarya dengan orientasi pada kinerja yang tinggi untuk mencapai tujuan akhir sebagaimana diharapkan oleh berbagai pihak. Sedangkan menurut Nugroho (2012), pemahaman good governance bertujuan untuk meningkatkan kinerja auditor melalui terciptanya proses pengambilan keputusan yang lebih baik.

Kinerja auditor yang didukung oleh beberapa faktor pendukung diharapkan mampu menyokong profesionalisme auditor, seperti apa yang diungkapkan oleh Arens, et. al. (2014:189) bahwa Kinerja auditor berdampak pada profesionalisme dan motivasi kerja. Sebab kemauan individu untuk melakukan usaha yang tinggi dalam upaya mencapai tujuan-tujuan organisasi dan memenuhi kebutuhankebutuhannya, membuat seseorang semakin memiliki motivasi kerja dalam dirinya. Selain itu, semakin baik kinerja auditor seseorang, maka semakin profesional dia di mata manajemen atau pihak luar. Jadi apabila kinerja yang dihasilkan baik, itu berarti profesionalisme yang dimiliki auditor tersebut tinggi.

Adapun pembahasan dari segi pengaruh tidak langsung yakni menurut Alwi (2015) komitmen organisasi yang dimiliki seseorang merupakan bentuk sejauh mana seseorang tersebut akan mengabdi pada organisasi. Bentuk pengabdiannya yaitu bekerja. Maka semakin tinggi komitmen organisasi seseorang maka kinerjanya semakin baik dan membuat auditor tersebut semakin profesional dalam bekerja. Sementara jika dilihat dari segi variabel gaya kepemimpinan yang menjadi pendorong, menurut Baihaqi (2014) gaya kepemimpinan yang baik dari seorang pimpinan kepada karyawannya akan mendukung kinerja kerja yang tinggi, sehingga dengan adanya kinerja yang tinggi, profesionalisme dalam bekerja pun akan muncul. Adapun pengaruh dari pemahaman good governance yaitu apabila Seorang akuntan yang memahami good governance secara benar maka akan mempengaruhi prilaku professional akuntan dalam dalam berkarya dengan orientasi pada kinerja yang tinggi untuk mencapai tujuan akhir sebagaimana diharapkan oleh berbagai pihak

\section{KESIMPULAN}

Berdasarkan hasil penelitian ditemukan bahwa komitmen organisasi, gaya kepemimpinan dan pemahaman good governance secara simultan berpengaruh terhadap kinerja auditor pada Kantor Akuntan Publik di Kota Bandung dengan pengaruh sebesar 59,4\% yang terdiri dari Komitmen organisasi memberikan pengaruh sebesar 23,2\%, Gaya kepemimpinan memberikan pengaruh sebesar 14,1\% dengan arah positif, dan Pemahaman good governance memberikan pengaruh sebesar $22,6 \%$.

Kinerja auditor memberikan pengaruh sebesar $61,1 \%$ terhadap profesionalisme auditor dengan arah positif, artinya semakin baik kinerja auditor akan membuat profesionalisme auditor semakin tinggi.

Secara tidak langsung melalui kinerja auditor, komitmen organisasi, gaya kepemimpinan dan pemahaman good governance berpengaruh terhadap profesionalisme auditor pada Kantor Akuntan Publik di Kota Bandung. Secara tidak langsung melalui kinerja auditor, komitmen organisasi memberikan pengaruh sebesar $32,7 \%$ terhadap profesionalisme auditor. Selanjutnya secara tidak langsung melalui kinerja auditor, gaya kepemimpinan memberikan pengaruh sebesar 23,8\% terhadap profesionalisme auditor. Terakhir secara tidak langsung melalui kinerja auditor, pemahaman good governance memberikan pengaruh sebesar $31,7 \%$ terhadap profesionalisme auditor.

\section{DAFTAR PUSTAKA}

Akriyanto, Rendy. 2012. Pengaruh Independensi, Gaya Kepemimpinan, Komitmen Organisasi, dan Pemahaman Good Corporate Governance terhadap Kinerja Auditor:study empiris pada auditor di KAP wilayah Surakarta dan Yogyakarta. Accounting Analysis Journal 1(2). Surakarta: Universitas Muhammadiah Surakarta

Alwi. 2015. Pengaruh Komitmen Organisasi dan Profesionalisme Terhadap Kinerja Auditor. Jurnal Bisnis dan Akuntansi. Vol.11.No.3.

Arens, A.A., Elder, R.J. and Mark, B., 2014. Auditing 
and assurance services: an integrated approach. Boston: Prentice Hall.

Baihaqi, Muhammad Fauzan. 2010. Pengaruh Gaya Kepemimpinan Terhadap Kepuasan Kerja dan Kinerja dengan Komitmen Organisasi Sebagai Variabel Intervening. Diponegoro Journal of Accounting Volume 1, Nomor 1.

Boynton, C., DeFilippes, P. and Legel, E., 2008. A first look at 2005 Schedule M-3 corporate reporting. Tax Notes, 121(5).

Kariyanti, Kartini. 2017. Pemimpin dan Kepemimpinan. Jakarta: PT. Raja Grafindo Persada.

Luthans, Fred. 2017. Organizational Behavior. Ninth Edition. McGraw-Hill. Inc., New York.

Mulyadi. 2014. Auditing. Buku 1. Edisi ke-6. Jakarta : Salemba Empat

Nugroho, Widhi Saputro. 2012. Pengaruh Komitmen Organisasi Dan Pemahaman Good Governance Terhadap Kinerja Auditor Pada Kantor Inspektorat Daerah Provinsi Lampung. Jurnal Akuntansi\&Keuangan.
Volume .3, No.2 September 2012.

Putri, H. E. dan Suraida, H. I., 2018. Pengaruh Profesiionalisme dan Komitmen Organisasi terhadap Kinerja Auditor Internal. (Doctoral dissertation, Perpustakaan Fakultas Ekonomi dan Bisnis Unpas Bandung).

Robbins, S.P dan Judge T.A. 2016. Perilaku Organisasi. Jakarta: Salemba Empat.

Sedarmayanti. 2014, Manajemen Sumber Daya Manusia. PT. Refika Aditama, Bandung.

Sugiyono. 2017. Metode Penelitian Kuantitatif, Kualitatif, dan R\&D. Bandung : Alfabeta

Suwanto, H. Priansa, Donni Juni, 2015. Manajemen SDM dalam Organisasi Publik dan Bisnis. Bandung : Alfabeta.

Tugiman, Hiro. 2014. Pandangan Baru Internal Auditing. Kanisius. Yogyakarta

Wirjana, Bernadine R., dan Susilo Supardo. 2005 Kepemimpinan, dasar-dasar dan pengembangannya. Yogyakarta, CV. Andi Offset.

Tabel 1. Operasionalisasi Variabel

\begin{tabular}{lllc}
\hline \multicolumn{1}{c}{ Variabel } & \multicolumn{1}{c}{ Definisi Operasional } & \multicolumn{1}{c}{ Dimensi Pengukuran } & Skala \\
\hline Komitmen & Sikap yang merefleksikan loyalitas karyawan pada organisasi dan & 1. Komitmen Afektif & Ordinal \\
Organisasi (X1) & $\begin{array}{l}\text { proses berkelanjutan dimana anggota organisasi mengekpresikan } \\
\text { perhatiannya terhadap organisasi dan keberhasilan serta }\end{array}$ & 2. Komitmen Berkelanjutan & 3. Komitmen Normatif \\
& $\begin{array}{l}\text { kemajuan yang berkelanjutan. (Luthans, 2017:249) } \\
\end{array}$ & &
\end{tabular}

Gaya

Kepemimpinan

(X2)

Pemahaman Good
Governance (X3)
Gaya kepemimpinan adalah sifat, kebiasaan, tempramen, watak dan kepribadian yang membedakan seorang pemimpin dalam berinteraksi dengan orang lain. (Kartono, 2017:34)
1. Kepemimpinan Secara Suportif

2. Kepemimpinan yang Direktif

3. Kepemimpinan Partisipatif

4. Kepemimpinan Berorientasi Prestasi

Ordinal

Seperangkat peraturan yang menetapkan hubungan antara 1. Keadilan

Ordinal pemegang saham, pengurus, pihak kreditur, pemerintah, 2. Transparansi karyawan serta para pemegang kepentingan intern dan ekstern 3. Akuntabilitas lainnya sehubungan dengan hak-hak dan kewajiban mereka. 4. Pertanggungjawaban (Suwanto, 2015 : 82)

Kinerja Auditor (Y)

Profesionalisme Auditor (Y)
Kinerja auditor adalah auditor yang melaksanakan penugasan $\quad 1$. Kemampuan pemeriksaan (examination) secara obyektif atas laporan 2. Komitmen Profesional keuangan suatu perusahaan (Mulyadi, 2014:126) 3. Motivasi 4. Kepuasan

Profesionalisme auditor yaitu kemampuan dan perilaku 1 . Pengabdian pada profesi profesional. Kemampuan didefinisikan sebagai pengetahuan, 2. Kewajiban Sosial pengalaman, kemampuan beradaptasi, kemampuan teknis, dan 3. Kemandirian kemampuan teknologi dll (Hiro Tugiman, 2014:119)
4. Keyakinan terhadap profesi

5. Hubungan sesama profesi

Ordinal

Ordinal 
Tabel 2 Anova Untuk Pengujian Secara Simultan

ANOVA $^{\mathrm{a}}$

\begin{tabular}{|c|c|c|c|c|c|c|}
\hline & odel & $\begin{array}{l}\text { Sum of } \\
\text { Squares }\end{array}$ & Df & $\begin{array}{l}\text { Mean } \\
\text { Square }\end{array}$ & $\mathrm{F}$ & Sig. \\
\hline \multirow[t]{3}{*}{1} & Regression & 8,247 & 3 & 2,749 & 29,794 &, $000^{\mathrm{b}}$ \\
\hline & Residual & 5,628 & 61 & ,092 & & \\
\hline & Total & 13,875 & 64 & & & \\
\hline
\end{tabular}

a. Dependent Variable: $\mathrm{Y}$

b. Predictors: (Constant), X3, X2, X1

Tabel 3. Koefisien Jalur Kinerja Auditor Terhadap Profesionalisme Auditor

Coefficients ${ }^{\mathrm{a}}$

\begin{tabular}{|c|c|c|c|c|c|}
\hline \multirow[b]{2}{*}{ Model } & \multicolumn{2}{|c|}{$\begin{array}{c}\text { Unstandardized } \\
\text { Coefficients }\end{array}$} & \multirow{2}{*}{$\begin{array}{c}\begin{array}{c}\text { Standardized } \\
\text { Coefficients }\end{array} \\
\text { Beta }\end{array}$} & \multirow[b]{2}{*}{$\mathrm{t}$} & \multirow[b]{2}{*}{ Sig. } \\
\hline & B & Std. Error & & & \\
\hline 1 (Constant) & ,651 & 230 & & 2,828 & ,006 \\
\hline $\mathrm{Y}$ & ,784 & ,079 & ,782 & 9,943 & ,000 \\
\hline
\end{tabular}

a. Dependent Variable: $\mathrm{Z}$
Tabel 4. Koefisien Determinasi Kinerja Auditor Terhadap Profesionalisme Auditor

Model Summary

\begin{tabular}{lcccc}
\hline Model & $\mathrm{R}$ & $\mathrm{R}$ Square & $\begin{array}{c}\text { Adjusted R } \\
\text { Square }\end{array}$ & $\begin{array}{c}\text { Std. Error of the } \\
\text { Estimate }\end{array}$ \\
\hline 1 &, $782^{\mathrm{a}}$ &, 611 &, 605 &, 29364 \\
\hline
\end{tabular}

a. Predictors: (Constant), Y

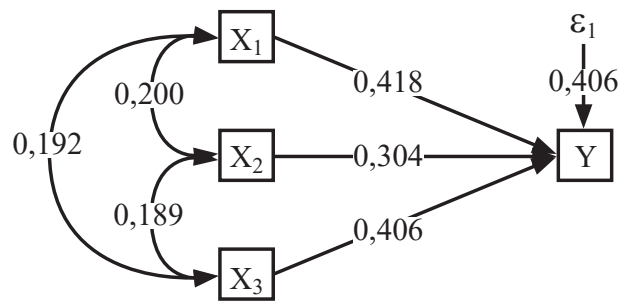

Gambar 1. Diagram Jalur Pada Pengujian Struktur Pertama

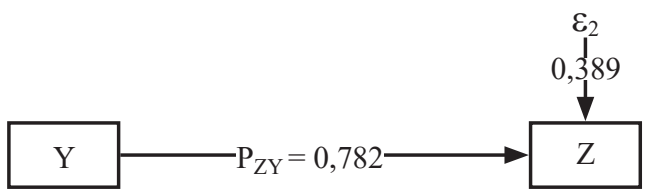

Gambar 2. Diagram Dan Koefisien Jalur Struktur Kedua 